\title{
DIFFERENT SHADING NETS IN ESCAROLE GROWTH
}

\author{
Daniela Meira $^{1 *}$, Daniele Cristina Fontana ${ }^{1}$, Carla Janaina Werner ${ }^{2}$, Thais Pollon Zanatta ${ }^{1}$, \\ Patricia Brezolin ${ }^{2}$, Braulio Otomar Caron ${ }^{3}$, Denise Schmidt ${ }^{3}$
}

\footnotetext{
${ }^{1}$ Mestranda no Programa de Pós-Graduação em Agronomia - Agricultura e Ambiente - Universidade Federal de Santa Maria, Campus Frederico Westphalen, Frederico Westphalen - RS *E-mail do autor correspondente: dmdanielameira94@gmail.com

${ }^{2}$ Graduada em Agronomia pela Universidade Federal de Santa Maria, Campus Frederico Westphalen, Frederico Westphalen - RS

${ }^{3}$ Professor Doutor do Departamento de Ciências Agrárias e Ambientais, Universidade Federal de Santa Maria, Campus Frederico Westphalen, Frederico Westphalen - RS.
}

\begin{abstract}
The aim of work was to verify the effect of different shading levels in escarole crop, during summer in the northwest of Rio Grande do Sul. The experiment was conducted at the Federal University of Santa Maria, Frederico Westphalen - RS Campus, in 2015 with Escarola Lisa escarole cultivar. The experimental design was a randomized complete block design with three shading levels $(0 \%, 30 \%, 50 \%)$, with six replications. Growth evaluation were performed in destructive manner every seven days, from transplant to harvest point. From the information obtained, traits were determined: leaf area, leaf area index, leaf area ratio, specific leaf area, leaf weight ratio, biological productivity, absolute growth rate, relative growth rate, net assimilation rate. The data obtained were analyzed by the statistical program Genes, the Tukey test at $5 \%$ of error probability. The shading level $30 \%$ provided greater leaf area, higher biological productivity and absolute growth rate. However, the leaf area ratio was higher when shading level $50 \%$ was tested. However, it can be said that the shading levels favor growth of escarole crop.
\end{abstract}

Key words: Chicorium endivia. Growth rate. Incident solar radiation.

\section{DIFERENTES NÍVEIS DE SOMBREAMENTO NO CRESCIMENTO DA CHICÓRIA}

RESUMO: O objetivo deste trabalho foi verificar o efeito de diferentes níveis de sombreamento sobre o crescimento da cultura da chicória, durante o verão na região noroeste do Rio Grande do Sul. O experimento foi realizado na Universidade Federal de Santa Maria, Campus Frederico Westphalen - RS, em 2015 com a cultivar de chicória Escarola Lisa. O delineamento experimental foi de blocos ao acaso, com três níveis de sombreamento $(0 \%, 30 \%, 50 \%)$, com seis repetições. As avaliações de crescimento foram realizadas de forma destrutiva a cada sete dias, do transplante até o ponto de colheita. A partir das informações obtidas foram determinadas as variáveis: área foliar, índice de área foliar, razão de área foliar, área foliar específica, razão de peso foliar, produtividade biológica, taxa de crescimento absoluto, taxa de crescimento relativo, taxa de assimilação líquida. Os dados obtidos foram analisados pelo programa estatístico Genes, ao teste de

Cultura Agronômica, Ilha Solteira, v.26, n.4, p.584-595, 2017 
Tukey a 5\% de probabilidade de erro. O nível de $30 \%$ de sombreamento proporcionou maior área foliar, maior produtividade biológica e taxa de crescimento absoluto. Contudo, a razão de área foliar foi superior quando testado $50 \%$ de sombreamento. Diante de tal, podese afirmar que os níveis de sombreamento auxiliam no crescimento da cultura da chicória.

Palavras-chave: Cichorium endivia. Taxa de crescimento. Radiação solar incidente.

\section{INTRODUCTION}

Cichorium endivia L. is a leafy vegetable of the Asteraceae family, and presents an important socioeconomic role in Brazil, providing food and generating employment and income for population (GOMES et al., 2016). Vegetable cultivated in field are exposed to numerous environmental adversities such as excessive rainfall, hail, frost, unfavorable temperatures (ANTUNES et al., 2007), as well as high solar radiation level that can result in qualitative and quantitative losses.

Solar radiation incidence is one of the most important sources of energy for plants, which is decisive for their vital processes (GUISELINI et al., 2010). Faced with this, demand for new technologies aimed the improving at cultivation environment is increasing. Shading nets, in turn, are used to minimize effect of solar radiation in vegetable crops, in addition to reducing effect of photoinhibition, reducing the luminosity and temperature (FU et al., 2012).

In this sense, nets use becomes viable alternative in several conditions of leafy vegetables cultivation (FU et al., 2012; SANTOS et al., 2010), providing to productivity increased, leaf size and leaf height of vegetative canopy (HIRATA; HIRATA, 2015).

Positive results have already been verified using shading levels, such as, Tullio et al. (2013) reported that shading level $70 \%$ reduces the maximum temperature until $10{ }^{\circ} \mathrm{C}$ when compared to natural environments on days with a high solar radiation incidence. However, the same authors verified that beet crop under shading level $70 \%$ did not present advantages in relation to natural environment cultivation in south of Brazil. For tomato crop in tutored system, shaded environments provide higher agronomic performance in the north of Minas Gerais, highlighting higher yield with shading level 50\%, as well as higher plant height (OTONI et al., 2012).

However, information regarding use appropriate shading nets and levels in escarole crops is scarce. The objective of this study was to verify effect of different shading levels on escarole growth during the summer, in the northwest region of Rio Grande do Sul.

\section{MATERIAL AND METHODS}

The present work was carried out at the Federal University of Santa Maria, Frederico Westphalen - RS Campus. The experimental area is located at coordinates $27^{\circ} 39^{\prime} \mathrm{S}$ and 
$53^{\circ} 42^{\prime} \mathrm{O}$, with an altitude of 490 meters. The climate of the region is classified as humid subtropical with annual average temperature of $19.1^{\circ} \mathrm{C}$ and average annual rainfall of 1880 mm (MALUF, 2000), with soil classified as Dystrophic Red Latosol (SANTOS et al., 2006).

The work was conducted with escarole (Cichorium endivia L.) Escarola Lisa cultivar. The experimental design was a randomized block design with three treatments, with different shading level: no shade (0\%); shading level 30\% and shading level 50\%, and six replicates, each plant being an experimental unit.

The beds were carried out with plowing and sorting, and the fertilization proceeded according to the interpretation of soil analysis, according to Comissão de Química e Fertilidade do Solo (CQFSRS/SC, 2004). The growth was carried out in beds of $1.2 \mathrm{~m}$ wide and the plants arranged in a spacing of $0.20 \times 0.25 \mathrm{~m}$. The seedlings were obtained in a vegetables nursey of Frederico Westphalen - RS, being the seeding was carried out on $01 / 07 / 2015$ and transplanted when they had three to four leaves $(02 / 03 / 2015)$.

The reference evapotranspiration (ETo) was calculated according to Penman (1948) and adapted by Monteith (1965). The daily water requirement was calculated by multiplying ETo by crop coefficient (Kc) (ALLEN et al., 1998), necessary irrigation being made available through the drip irrigation system. The growth evaluations were performed destructive evalutaion every seven days, from transplant date to harvest point, which was established when the plants reached a larger leaf area and previous period the beginning of the floral stem elongation, period from February $3^{\text {th }}$ to March $31^{\text {st }}, 2015$.

For the evaluations, six plants of each treatment were used, that is six repetitions, where the traits were analyzed: number of leaves $>5 \mathrm{~cm}$, number of leaves $<5 \mathrm{~cm}$, dry mass of discs, dry mass of leaves, stem and residues $\left(\mathrm{g}\right.$ plant $\left.{ }^{-1}\right)$. To determine the dry mass, samples were packed in a paper bag and transferred to the oven for drying at $72{ }^{\circ} \mathrm{C}$ until reaching constant weight, and after being weighed in a precision balance.

According to results of the above traits mentioned, parameters for the growth analysis were determined, according to Benincasa (2004) and Magalhães (1985):

- Leaf Area (LA):

$$
\text { LA: } \frac{\text { nd. ad. MST }}{\text { MSd. MSf }}
$$

Where nd: number of discs, ad: punch disc area $\left(\mathrm{m}^{2}\right)$, MST: total dry mass, MSd: dry mass of discs, MSf: dry mass of leaves, expressed in $\mathrm{dm}^{2}$.

- Leaf Area Index (LAI): ratio between leaf area (LA) and soil area (SA, m²) occupied by plant, expressed in $\mathrm{g} \mathrm{dm}^{2}$.

\section{LAI: LA/SA}

- Leaf area ratio (LAR): expresses relationship between leaf area (LA, $\left.\mathrm{dm}^{2}\right)$ and the weight of the dry mass of aerial part of plant (MST, g), expressed in $\mathrm{dm}^{2} \mathrm{~g}^{-1}$. 


\section{LAR: $\frac{\text { LA }}{\text { MST }}$}

- Specific leaf area (SLA): leaf area (LA) by total dry mass of plant (MST), expressed in $\mathrm{dm}^{2} \mathrm{~g}-{ }^{1}$.

- Leaf weight ratio (LWR): ratio dry mass of leaves by for dry mass of total plant, expressed in $\mathrm{g}^{1}{ }^{1}$ day.

- Biological productivity (BP): presents a ratio between total dry mass (TDM) by soil area (SA), expressed in $\mathrm{g} \mathrm{dm}^{-2}$.

\section{BP: TDM/SA}

- Absolute growth rate (AGR): increase between two assessments over time, represented by the expression:

$$
\text { AGR: } \frac{\mathrm{TDM}_{2}-\mathrm{TDM}_{1}}{\mathrm{t}_{2}-\mathrm{t}_{1}}
$$

Where: TDM2 represents total dry mass of the final aerial part (g); TDM1 is total dry mass of initial aerial part $(\mathrm{g})$; And $\mathrm{t} 2$ - $\mathrm{t} 1$ indicates the time interval between two evaluations, expressed in $\mathrm{g} \mathrm{day}^{-1}$.

- Relative growth rate (RGR): indicates increment of dry mass in a given time interval. That is, difference of dry mass of aerial part of plant by period of days between evaluations, where ln indicates natural logarithm, expressed in $\mathrm{g} \mathrm{g}^{-1}$ day.

$$
\mathrm{RGR}: \frac{\ln \mathrm{TDM}_{2}-\ln \mathrm{TDM}_{1}}{\mathrm{t}_{2}-\mathrm{t}_{1}}
$$

- Net assimilation rate (NAR): plant growth response to environmental conditions can be evaluated, that is, it represents the efficiency of a plant in accumulating dry matter expressed by $\mathrm{g} \mathrm{dm}^{2} \mathrm{day}^{-1}$.

$$
\text { NAR: }\left(\frac{\mathrm{TDM}_{2}-\mathrm{TDM}_{1}}{\mathrm{t}_{2}-\mathrm{t}_{1}}\right)\left(\frac{\operatorname{lnTDM}_{2}-\operatorname{lnTDM}_{1}}{\mathrm{t}_{2}-\mathrm{t}_{1}}\right)
$$

Data obtained were analyzed by statistical program Genes (CRUZ, 2013), and means of each treatment submitted to Tukey test at 5\% of error probability.

\section{RESULTS AND DISCUSSION}

Figures 1 and 2 show meteorological data collected from Frederico Westphalen - RS automatic weather station during growing season.

Air temperature is one of determining meteorological elements in the crop development rate, influencing period necessary to reach harvest point (BECKMANNCAVALCANTE et al., 2009). This dependence is due to speed of chemical reactions and internal processes of sap transport, and to normal development of plants that are accelerated. 
During the evaluations, minimum and maximum temperatures of 12.5 and $33.0{ }^{\circ} \mathrm{C}$ were observed, respectively (Figure 1). However, due to lack of knowledge of ideal conditions for escarole crop, it is assumed that the maximum temperatures that occurred are above ideas for the development of the crop.

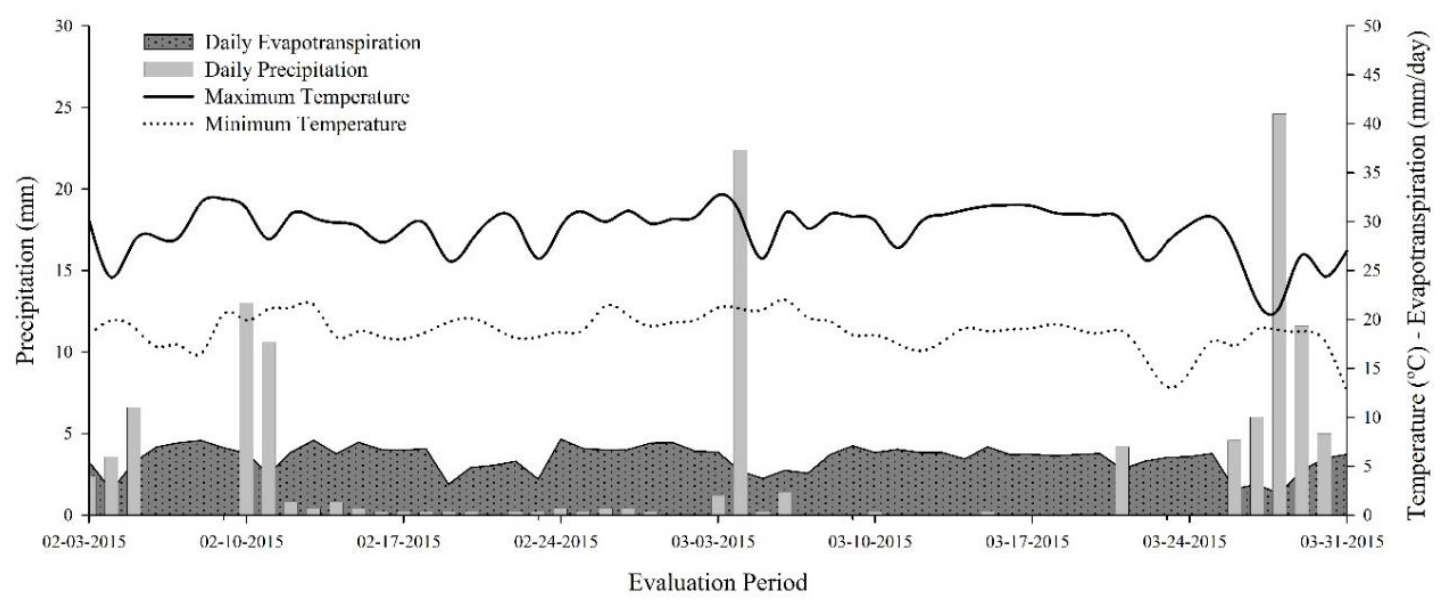

Figure 1. Meteorological data of daily precipitation, maximum and minimum temperatures, and evapotranspiration during escarole crop (Cichorium endivia L.) Escarola Lisa cultivar. Source: INMET, (Frederico Westphalen - A854) Frederico Westphalen - RS automatic weather station.

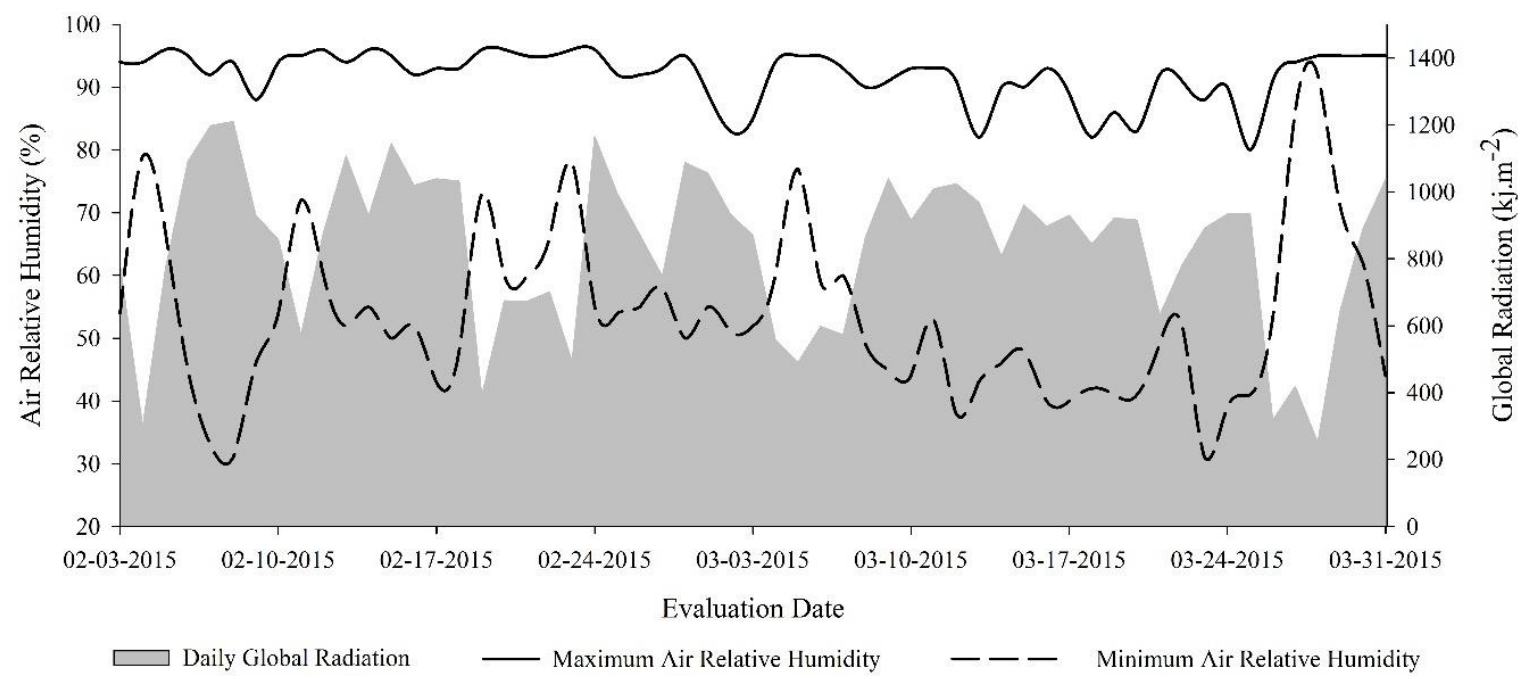

Figure 2. Meteorological data of maximum and minimum daily air relative humidity and global radiation during the escarole (Cichorium endivia L.) Escarola Lisa cultivar.

Source: INMET, (Frederico Westphalen - A854) Frederico Westphalen - RS automatic weather station (2017).

Statistical analysis revealed significance for both traits analyzed, and the results for levels of shading are shown in Figures 3 and 4. In these figures are growth indicators analyzed during the evaluations.

The highest leaf area indexes were found in last evaluations of escarole crop (Figure 3 - A). The shading levels presented differences only after seventh evaluation, where shading of $30 \%$ exceed to level $0 \%$. In the evaluation performed on March $24^{\text {th }}$, it can be observed 
that the shading of $50 \%$ expressed superiority, and in evaluation performed at the harvesting point $(03 / 31)$ it is evident that use of shading in escarole crop increased LAI. Ferreira et al. (2014), attribute the performance in conditions of lower temperatures to Mediterranean origin. This adaptation favors larger leaves, greater fresh plant mass ${ }^{-1}$ and greater specific leaf area (FERREIRA et al., 2009).

The efficiency of the use of shading nets, shading of $50 \%$, can be proven with the increase of seeds germination of agricultural interest species for north region of country (MOURA et al., 2015). For watercress culture cultivated in São Paulo state, black and silver shading nets with level $35 \%$ of shading provided an increase in yield (HIRATA; HIRATA, 2015).

The highest leaf area indexes verified in the last evaluations are in agreement with fast vegetative growth near harvest point, with the leaves presenting a larger photosynthetic area (CARVALHO et al., 2009). Therefore, the mild conditions provided by shading condition greater vegetative growth of plants and greater interception of diffuse solar radiation, justifying the efficiency of use shading nets in the highest index of leaf area.
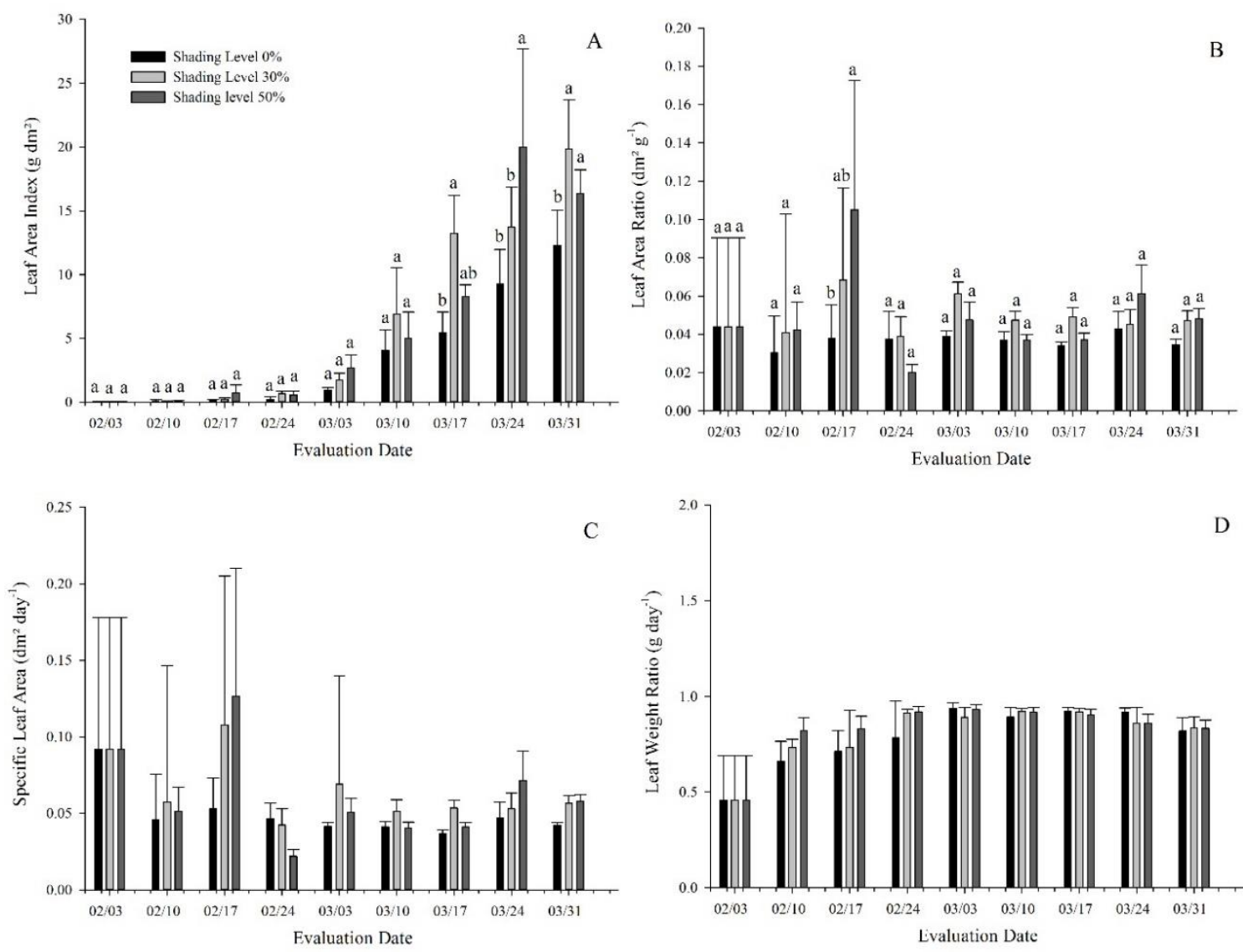

*Averages followed by the same lowercase letter and figure without letters do not differ statistically by Tukey test at $5 \%$ probability of error.

Figure 3. Leaf area index (A), leaf area ratio (B), specific leaf area (C), leaf weight ratio (D) for shading levels $(0 \%, 30 \%$ and 50\%) in escarole crop in 2015.

Cultura Agronômica, Ilha Solteira, v.26, n.4, p.584-595, 2017 
In third week after transplanting, there was difference between shading levels for leaf area ratio (LAR), and the shading level $50 \%$ presented a superiority in relation to level $0 \%$ (Figure 3 - B). The highest vegetative growth in the production of sweet passion fruit seedlings, in southeast of Brazil is reported by Freitas et al. (2015) using two and three shading nets, 0.70 and $0.40 \mu \mathrm{mol} \mathrm{m} \mathrm{m}^{-2} \mathrm{~s}^{-1}$ respectively (representing $18 \%$ and $53 \%$ of shading level).

Lettuce cultivars respond significantly to use of shading nets, and level $50 \%$ provided high LAR values at 20 days after seeding, and after a marked decline (ZUFFO et al., 2016), corroborating with data obtained. This decrease is related to auto-shading, drying and fall leaves of plant. At this stage, most of the photosynthesized material is accumulated in aerial biomass of lettuce to better capture available solar radiation (CARON et al., 2007).

The link between leaf area and dry mass is narrow, because they are leaves that compose greater fraction aerial part escarole phytomass. In this way, the increase of leaf area during the cycle expresses increase useful foliar area (BENINCASA, 2003), thus determining the increase dry mass, not showing large oscillations among evaluation dates. One of factors that directly influences phytomass formation is the solar radiation, therefore, shading level infers in this reason, since it determines foliar apparatus of vegetable, influencing in solar energy interception.

Radiation is important in plant growth not only by providing energy for photosynthesis, but also by providing signals that regulate its development through light receptors sensitive to different intensities (TAIZ et al., 2017). However, the higher shading provided by level $50 \%$ conditioned the decrease in air temperature values, which may have directly implicated stomatal opening mechanism, $\mathrm{CO}_{2}$ assimilation for photosynthesis, photoassimilate distribution and leaf expansion.

The specific leaf area (SLA) presented a greater magnitude in the first and third evaluation and decrease in subsequent evaluations, because according vegetation develops the photo-assimilate translocation is triggered, increasing the biomass and reducing specific leaf area (Figure 4 - C). At the beginning of crop development, there is a great accumulation of reserves, and leaves are still not thick and do not present high biomass, so high SLA occurs (BENINCASA, 2003).

Leaf weight ratio (LWR) increased from first to second evaluation, and stability up to harvest point on March $31^{\text {st }}$ (Figure 3 - D). This contents increase is related to photoassimilates exportation of leaf to drains of plant, and consequently smaller mass retained in leaves (ZUFFO et al., 2016). The plants growth depends on the balance of dry matter accumulated by photosynthesis.

Healthy plants that have adequate quantities of water and nutrients, dry phytomass production is governed by photosynthetically active radiation (MONTEITH, 1965). From the fourth week, LWR values stabilized due to photo-assimilate translocation characteristic and the shade levels tested did not influence significantly (Figure 3-D).

Cultura Agronômica, Ilha Solteira, v.26, n.4, p.584-595, 2017 

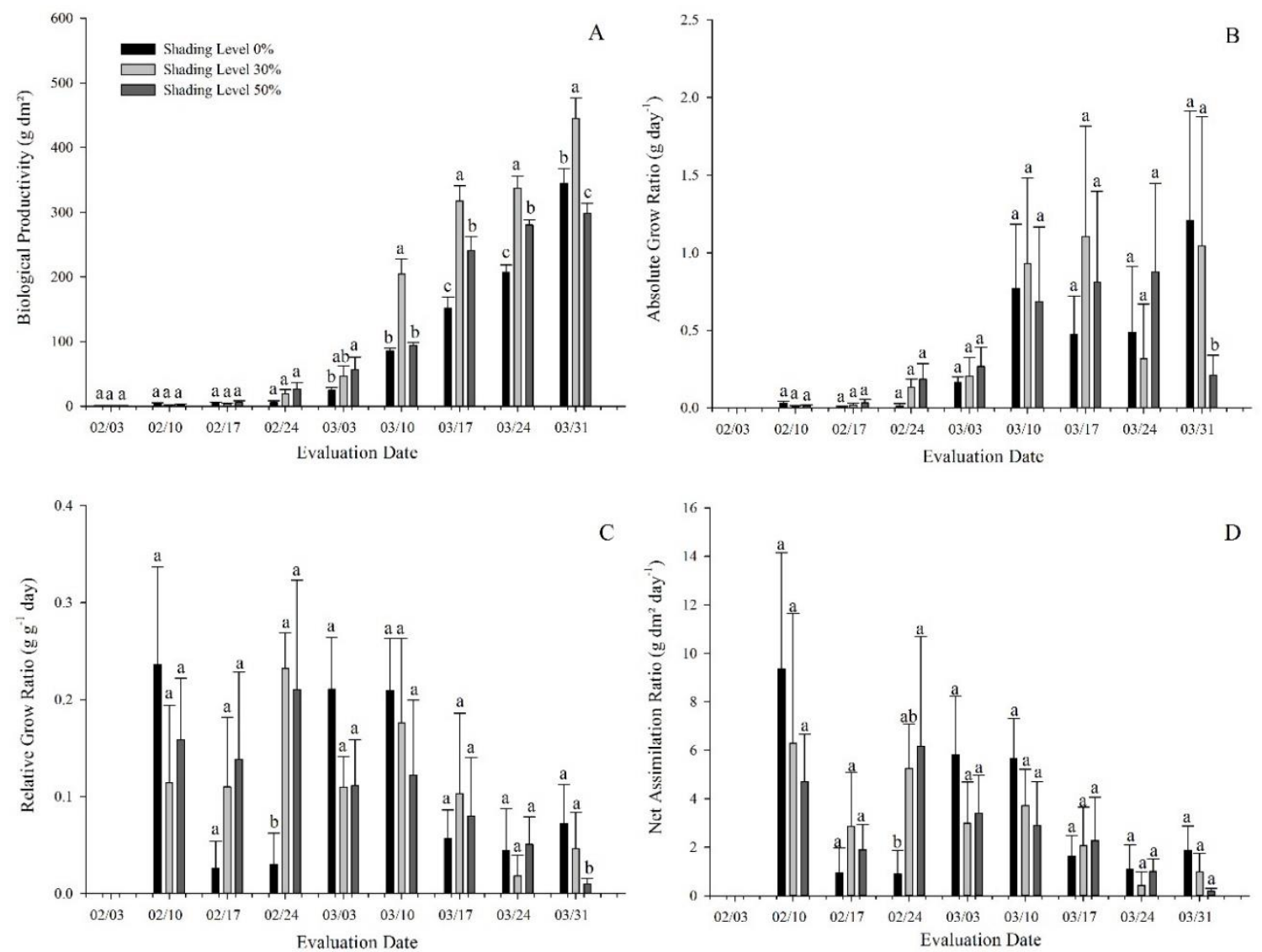

*Averages followed by the same lowercase letter do not differ statistically by Tukey test at $5 \%$ probability of error.

Figure 4. Biological productivity (A), absolute growth rate $(\mathrm{B})$, relative grow ratio $(\mathrm{C})$ and net assimilation ratio (D) for shading levels (0\%, 30\% and 50\%) in escarole crop in 2015.

In the representation of the biological productivity (BP) (Figure 4 - A), it can be observed that there was a significant difference from fifth week after transplantation, and shading level 50\% showed greater efficiency in the plant growth. The reduced growth in first weeks is tied to initial adaptation period of the crop. From sixth evaluation, the shading level 30\% was outstanding for the others. Thus, the increase in BP was better at level $30 \%$ due to the reduction of solar radiation and temperature, thus providing ideal conditions to produce higher volumes of dry matter per soil area.

For the absolute growth rate (AGR) significant increase of dry mass was observed only in last evaluation, with shading levels 0 and 30\% being outstanding (Figure $4-\mathrm{B}$ ). Given this, the low increment obtained by level $50 \%$ is justified by the stabilization of crop growth at end of cycle, since in the seventh evaluation, this level gave the highest BP.

The dry matter increment speed tends to vary rapidly, since from eighth to the ninth week of evaluation (harvest point) great precipitation occurred, triggering high relative air humidity and lowering the maximum and minimum temperatures (Figure 1 and 2 ), modifying the increment. In view of this, it is confirmed that higher shading level associated 
with these meteorological conditions, delayed the photoassimilates translocation rate, drastically reducing the productive performance of escarole crop.

Considering relative growth rate (RGR), there was an oscillation between the evaluation dates and shading levels, and the tendency of the rate to decrease according to crop cycle. It was also observed that in the fourth evaluation week $(02 / 24 / 2015)$ there was a significant difference for shading levels, and shading levels 30 and 50\% stood out.

However, in the last week of evaluation (03/31/2015), shading levels 0 and $30 \%$ increased, differing significantly from 50\% level (Figure 4 - C). Some authors report that this observed decrease is due to high respiratory activity and auto shading that increases with passing of crop cycle, and in this period, the growth can become negative, due to death of plant organs such as leaves and buds (BARREIRO et al., 2006; BECKMANNCAVALCANTE et al., 2009).

The species behavior is largely explained by meteorological conditions, because the period that preceded fourth evaluation was dry period (low relative air humidity). Another factor that may have inferred in the increase of dry matter was period with low daily evapotranspiration and low global radiation (Figure 1 and 2), providing better conditions for shading plants (30 and 50\%). These levels allowed an environment with lower temperatures and, consequently, maintenance of higher levels of humidity, allowing the plants to increase dry matter.

However, the high rainfall occurred in last week of evaluation, together with high relative air humidity, and the lower values of temperature and global radiation, conditioned a greater increase and photoassimilates translocation to the plants submitted to the lowest shading levels. This fact is related to the efficiency of absorption of these plants to small levels of radiation that affected.

Net assimilation rate (NAR) decreased as a function of period escarole growth, and only in fourth week the level $50 \%$ presented superiority compared to other shading levels (Figure 4 - D). This behavior was verified by some authors, justifying that NAR tends to be larger at beginning of cycle (GONDIM et al., 2008). This is due to some factors such as photosynthetic rate, leaf size, vegetative period, canopy leaf distribution, leaf angle and assimilated distribution (PEDÓ et al., 2010).

The efficiency of escarole plants submitted to shading levels, verified by NAR, indicates that higher shading is more efficient the photosynthetic balance in dry matter production and consequent increase in biomass per unit area of leaf (CARON et al., 2012).

\section{CONCLUSION}

Use of shading nets provides an increase in leaf area, leaf area ratio, biological productivity, net assimilation rate, thus showing that use of shading nets with levels $30 \%$ and $50 \%$ positively assists in escarole growth in the summer. 


\section{REFERENCES}

ALLEN, R. G.; PEREIRA, L. S.; RAES, K.; SMITH, M. Crop evapotranspiration guidelins for computing grop water requirements. 1 ed Rome: FAO, 1998. 300 p. (FAO Irrigation and Drainage Paper, 56)

ANTUNES, O. T.; CAlvete, E. O.; ROCHA, C.; NIENOW, A. A.; CECCHETTI, D.; RIVA, M. R. Produção de cultivares de morangueiro polinizadas pela abelha jataí em ambiente protegido. Horticultura Brasileira, Brasília, v. 25, n. 1, p.60-65, 2007. Available in: http://www.scielo.br/scielo.php?script=sci_arttext\&pid=S0102-05362007000100018. Accessed in: 14 oct. 2016.

BARREIRO, A. P.; ZUCARELI, V.; ONO, E. O.; RODRIGUES, J. D. Análise de crescimento de plantas de manjericão tratadas com reguladores vegetais. Bragantia, Campinas, v. 65, n. 4, p.563-567, 2006.

BECKMANN-CAVALCANTE, M. Z.; PIVETTA, K. F. L.; CAVALCANTE, Í. H. L.; CAVALCANTE, L. F.; BELLINGIERI, P. A. Soluções nutritivas no desenvolvimento do Crisântemo cultivado em vaso. Irriga, Botucatu, v. 14, n. 2, p.205-219, 2009.

BENINCASA, M. M. P. Análise de Crescimento de Plantas (noções básicas). 3 ed. Jaboticabal: FUNEP, 2004. 41 p.

CARON, B. O.; MANFRON, P. A.; LÚCIO, A. D.; SCHMIDT, S.; MEDEIROS, S. L. P.; BONNECARRÉRE, R. A. G.; NETO, D. D. Equações de estimativa da fitomassa da parte aérea da alface. Ciência Rural, Santa Maria, v. 37, n. 5, p.1248-1254, 2007. Available in: http://www.scielo.br/pdf/cr/v37n5/a05v37n5.pdf. Accessed in: 15 oct. 2016.

CARON, B. O.; SOUZA, V. Q.; TREVISAN, R.; BEHLING, A.; SCHMIDT, D.; BAMBERG, R.; ELOY, E. Eficiência de conversão da radiação fotossinteticamente ativa interceptada em fitomassa de mudas de eucalipto. Revista Árvore, Viçosa, v. 36, n. 5, p.833-842, 2012.

Available in: http://www.scielo.br/scielo.php?script=sci_arttext\&pid=S0100-67622012000500005. Accessed in: 10 jan. 2017.

CARVAlHO, C. A. L.; DANTAS, A. C. V. L.; PEREIRA, F. A. C.; SOARES, A. C. F.; MELO FILHO, J. F.; OLIVEIRA, G. J. C. Tópicos em ciências agrárias. Cruz das Almas: Universidade Federal do Recôncavo da Bahia, 2009. 296p.

COMISSÃO DE QUÍMICA E FERTILIDADE DO SOLO - CQFSRS/SC. Manual de adubação e calagem para os estados do Rio Grande do Sul e Santa Catarina. 10 ed. Porto Alegre: Sociedade Brasileira de Ciência do Solo/Núcleo Regional Sul, 2004. 400 p.

CRUZ, C. D. GENES - a software package for analysis in experimental statistics and quantitative genetics. Acta Scientiarum Agronomy, Maringá, v. 35, n. 3, p.271-27, 2013.

FERREIRA, M. G. R.; ROCHA, R. B.; GONÇALVES, E. P.; ALVES, E. U.; RIBEIRO, G. D. Influência do substrato no crescimento de mudas de cupuaçu (Theobroma grandiflorum Cultura Agronômica, Ilha Solteira, v.26, n.4, p.584-595, 2017 
Schum.). Acta Scientiarum Agronomy, Maringá, v. 31, n. 4, p.677-681, 2009. Available in: http://periodicos.uem.br/ojs/index.php/ActaSciAgron/article/view/3092/3092. Accessed in: 25 nov. 2016.

FERREIRA, R. L. F.; ALVES, A. S. S. C.; ARAÚJO NETO, S. E.; KUSDRA, J. F.; REZENDE, M. I. F. L. Produção orgânica de alface em diferentes épocas de cultivo e sistemas de preparo e cobertura de solo. Bioscience Journal, Uberlandia, v. 30, n. 4, p.1017-1023, 2014. Available in http://www.seer.ufu.br/index.php/biosciencejournal/article/view/21864/14747. Acessed in: 2 mar. 2017.

FREITAS, A. R.; LOPES, J. C.; ALEXANDRE, R. S.; VENANCIO, L. P. V.; ZANOTTI, R. F. Emergência e crescimento de mudas de maracujá doce em função do lodo de esgoto e luz. Cumunicata Scientiae, Bom Jesus, v. 6, n. 2, p.234-240, 2015. Available in: https://comunicatascientiae.com.br/comunicata/article/viewFile/745/322. Accessed in: 15 Feb. 2017.

FU, W.; LI, P.; WU, Y. Effects of different light intensities on chlorophyll fluorescence characteristics and yield in lettuce. Scientia Horticulturae, Netherlands, v. 135, p.45-51, 2012.

GOMES, G. P.; AZEREDO, L. S. G.; SEKIYA, A.; EUZEBIO, M. P.; ROBAINA, R. R.; MARINHO, C. D. Registro e proteção de olerícolas no Brasil, período de 1998 a 2014. Horticultura Brasileira, Brasília, v. 34, n. 1, p.19-25, 2016. Available in: http://www.scielo.br/scielo.php?script=sci_arttext\&pid=S0102-05362016000100019 Accessed in: 16 feb. 2017.

GONDIM, A. R. O.; PUIATTI, M.; VENTREllA, M. C.; CECON, P. R. Plasticidade anatômica da folha de taro cultivado sob diferentes condições de sombreamento. Bragantia, Campinas, v. 67, n. 4, p.1037-1045, 2008. Available in: http://www.scielo.br/pdf/brag/v67n4/28.pdf. Accessed in: 17 dec. 2016.

GUISElini, C.; SENTElHAS, P. C.; PANDORFI, H.; HOLCMAN, E. Manejo da cobertura de ambientes protegidos: Radiação solar e seus efeitos na produção da gérbera. Revista Brasileira de Engenharia Agrícola e Ambiental, Campina Grande, v. 14, n. 6, p.645-652, 2010. Available in: http://www.scielo.br/pdf/rbeaa/v14n6/a11v14n6.pdf. Accessed in: 17 oct. 2016.

HIRATA, A. C. S.; HIRATA, E. K. Desempenho produtivo do agrião d'água cultivado em solo sob telas de sombreamento. Revista Pesquisa Agropecuária Brasileira, Brasília, v. 50, n. 10, p.895-901, 2015. Available in: http://www.scielo.br/pdf/pab/v50n10/1678-3921pab-50-10-00895.pdf. Accessed in: 15 feb. 2017.

MAGALHÃES, A. C. N. Análise quantitativa do crescimento. In: FERRI, M. G. Fisiologia Vegetal. 2. ed., v. 1. São Paulo: Editoras EPU / EDUSP, 1985. p. 331-350.

MALUF, J. R. T. Nova classificação climática do Estado do Rio Grande do Sul. Revista 
Brasileira de Agrometeorologia, Santa Maria, v. 8, n. 1, p.141-150. 2000.

MONTEITH, J. L. Evaporation and Environment. In: SYMPOSIUM OF THE SOCIETY FOR EXPERIMENTAL BIOLOGY, 1965, New York. Anais... New York: The State and Movement of Water in Living Organisms, v. 19, 1965. p.205-239.

MOURA, E. A.; CHAGAS, P. C.; MOURA, M. L. S.; SOUZA, O. M.; CHAGAS, E. A. Emergência e desenvolvimento inicial de plântulas de cupuaçu cultivadas sob diferentes substratos e condições de sombreamento. Revista Agro@mbiente, Boa Vista, v. 9, n. 4, p.405-413, 2015. Available in: http://revista.ufrr.br/agroambiente/article/view/2597/1878. Accessed in: 25. nov. 2016.

OTONI, B. S.; MOTA, W. F.; BELFORT, G. R.; SILVA, A. R. S.; VIEIRA, J. C. B.; ROCHA, L. S. Produção de híbridos de tomateiro cultivados sob diferentes porcentagens de sombreamento. Revista Ceres, Viçosa, v. 59, n. 6, p.816-825, 2012.

PEDÓ, T.; LOPES, N. F.; MORAES, D. M.; AUMONDE, T. Z.; SACARRO, E. L. Crescimento de três cultivares de rabanete (Raphanus sativus) ao longo da ontogenia das plantas. Tecnologia \& Ciência Agropecuária, João Pessoa, v. 4, n. 3, p.17-21, 2010.

PENMAN, M. L. Evaporation: in introductory survey. Netherlands Journal of Agricultura Science, Netherlands, v. 4, n. 1, p.9-29, 1948.

SANTOS, H. G.; JACOMINE, P. K. T.; ANJOS, L. H. C.; OLIVEIRA, V. A.; OLIVEIRA, J. B.; COELHO, M. R.; LUMBRERAS, J. F.; CUNHA, T. J. F. Sistema brasileiro de classificação de solos. Embrapa. 2. ed. Rio de Janeiro: EMBRAPA, 2006. 306 p.

SANTOS, L. L.; SEABRA JR. S.; NUNES, M. C. M. Luminosidade, temperatura do ar e do solo em ambientes de cultivo protegido. Revista de Ciências Agroambientais, Alta Floresta, v. $8, \quad$ n. $3, \quad$ p.83-93, 2010. Available in: http://www.unemat.br/revistas/rcaa/docs/vol8/8_artigo_v8.pdf . Accessed in: 2 mar. 2017.

TAIZ, L.; ZEIGER, E.; MOLLER, I. M.; MURPHY, A. Fisiologia e desenvolvimento vegetal. 6. ed. Porto Alegre: Artmed, 2017. 858 p.

TUlLIO, J. A; OTTO, R. F.; BOERL, A.; OHSE, S. Cultivo de beterraba em ambientes protegido e natural na época de verão. Revista Brasileira Engenharia Agrícola Ambiental, Campina Grande, v. 17, n. 10, p.1074-1079, 2013. Available in: http://www.scielo.br/scielo.php?script=sci_arttext\&pid=S1415-43662013001000008. Accessed in: 25 nov. 2016.

ZUFFO, A. M.; ZUFFO JÚNIOR, J. M.; SILVA, L. M. A.; SILVA, R. L.; MENEZES, K. O. Análise de crescimento em cultivares de alface nas condições do Piauí. Revista Ceres, Viçosa, v. 63, n. 2, p.145-153, 2016.

Cultura Agronômica, Ilha Solteira, v.26, n.4, p.584-595, 2017 